\title{
Erythorbic Acid Content in Tissues of Guinea Pigs Administered Erythorbic Acid
}

\author{
Emiko Suzuki, Tadao Kurata, Miyoko KodA, \\ and Nobuhiko ARAKAWA ${ }^{1}$ \\ Department of Food and Nutrition, Ochanomizu University, \\ Otsuka, Bunkyo-ku, Tokyo 112, Japan
}

(Received January 29, 1987)

\begin{abstract}
Summary The erythorbic acid (ErA) content in the tissues of guinea pigs administered ErA was compared with that of ascorbic acid (AsA). Guinea pigs were administered 1, 5, 20, and $100 \mathrm{mg} \mathrm{ErA/day} \mathrm{or} \mathrm{1,} \mathrm{5,} \mathrm{and}$ $100 \mathrm{mg} \mathrm{AsA} /$ day for 16 days and then sacrificed. The liver, adrenal glands, spleen, and kidneys were removed to determine the contents of ErA and AsA using HPLC. Only a small amount of ErA was found in four tissues of the animals administered $20 \mathrm{mg}$ or more of ErA/day. On the contrary, AsA was found in the tissues of all animals administered $1 \mathrm{mg}$ or more of AsA/day. The ErA content in the tissues was much lower than that of AsA even when the amount of ErA administered was the same as that of AsA. However, the body weight gains of animals administered ErA were similar to those of animals administered AsA. These observations suggested that the mechanism of the retention of ErA in the tissues was much different from that of AsA and that the vitamin $\mathrm{C}$ activity of ErA might be more than one-twentieth that of AsA.
\end{abstract}

Key Words erythorbic acid, ascorbic acid, guinea pig

Erythorbic acid (ErA) is one of the stereoisomers of L-ascorbic acid (AsA). The vitamin $\mathrm{C}$ activity of ErA has been reported by several workers (1-4) who showed that the vitamin $\mathrm{C}$ activity of ErA was much less than that of AsA. For instance, Demole (1) reported that the antiscorbutic activity of ErA was one-twentieth that of AsA. Also, Yourga et al.(2) reached the same conclusion based on an experiment on the determination of the 25-day weight response of guinea pigs. Zilva (3) found by titration with 2,6-dichlorophenolindophenol that the content of total AsA, which is the sum of AsA and ErA contents, in the tissues of animals injected with ErA was lower than that of AsA in animals injected with AsA. Fabianek and Herp (4) reported on the content of total AsA (AsA plus ErA) in the tissues of guinea pigs supplemented with graded doses of ErA using their modified

1 鈴木恵美子, 倉田忠男, 甲田み上子, 荒川信彦 
2,4-dinitrophenylhydrazine method.

The workers described above did not measure ErA and AsA separately in the tissues, since at that time there was no reliable, separative determination method for AsA and ErA. However, in our previous study we determined ErA and AsA simultaneously in the tissues of guinea pigs administered both AsA and ErA using high-performance liquid chromatography (HPLC) (5). Furthermore, we found that a large amount of ErA administered to guinea pigs for 30 days prevented the occurrence of scurvy and a complete recovery of body weight was seen when ErA was administered to AsA-deficient guinea pigs (5).

In previous papers $(5,6)$, we studied the effect of ErA administration on the AsA content in the tissues of the guinea pigs administered both AsA and ErA. In this paper, we used HPLC to determine the ErA content in the tissues of guinea pigs administered various levels of ErA, and also discuss the vitamin C activity of ErA.

\section{MATERIALS AND METHODS}

Animals and diet. Male albino guinea pigs (Hartley strain) with initial body weights of about $220 \mathrm{~g}$ were used. All animals were housed individually in wire cages, and maintained on the AsA-deficient diet descrided previously (5). Water and diets were offered ad libitum, and their body weights were recorded daily.

Experimental design. All animals were randomly divided into seven groups. Group A was orally supplemented with $1 \mathrm{mg} \mathrm{AsA/day,} \mathrm{group} \mathrm{B} \mathrm{with} 5 \mathrm{mg} \mathrm{AsA/day,}$ group $\mathrm{C}$ with $100 \mathrm{mg} \mathrm{AsA} /$ day, group D with $1 \mathrm{mg} \mathrm{ErA/day,} \mathrm{group} \mathrm{E} \mathrm{with} 5 \mathrm{mg}$ ErA/day, group F with $20 \mathrm{mg} \mathrm{ErA/day,} \mathrm{and} \mathrm{group} \mathrm{G}$ with $100 \mathrm{mg} \mathrm{ErA/day.} \mathrm{AsA}$ or ErA was dissolved in water immediately before use.

On day 16 of the experimental period, the animals were sacrificed after $24 \mathrm{~h}$ fasting. Their liver, adrenal glands, spleen, and kidneys were immediately removed to determine the AsA and ErA contents.

Determination of AsA and ErA. The AsA and ErA contents in the tissues were simultaneously determined using HPLC as described previously (5).

Statistical tests. The significant difference between the means of two groups was statistically analyzed by Student's $t$-test or the Cochran-Cox test, depending on whether the variances were equal or different, respectively.

\section{RESULTS}

Figure 1 shows the average body weight gains of the experimental groups. The body weights of all groups continued to increase during the experimental period. Neither the AsA- nor the ErA-supplemented groups showed body weight loss.

Table 1 shows the AsA and ErA contents in the liver of guinea pigs administered AsA or ErA. AsA was found in the liver of all animals administered AsA and its content increased with increasing AsA dosage. However, among the ErA-supplemented groups, AsA was not found in the liver of groups D, E, and F, 


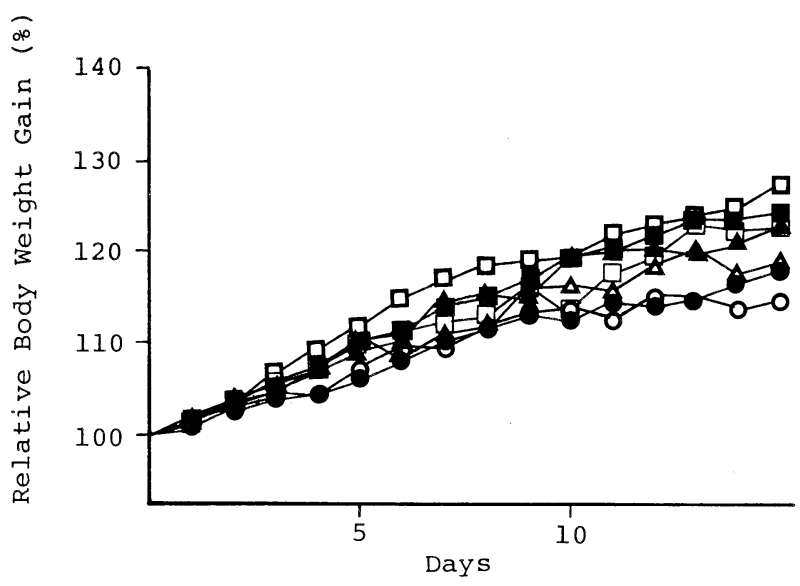

Fig. 1. Body weight changes of guinea pigs supplemented with AsA or ErA. Group A $(\bullet), 1 \mathrm{mg}$ AsA supplemented group; group B ( $\mathbf{\Delta}), 5 \mathrm{mg}$ AsA supplemented group; group $\mathrm{C}(\boldsymbol{\square}), 100 \mathrm{mg}$ AsA supplemented group; group D (O), $1 \mathrm{mg}$ ErA supplemented group; group $\mathrm{E}(\triangle), 5 \mathrm{mg}$ ErA supplemented group; group $\mathrm{F}(\square), 20 \mathrm{mg}$ ErA supplemented group; group $\mathrm{G}(\square), 100 \mathrm{mg}$ ErA supplemented group.

Table 1. AsA and ErA contents in livers of guinea pigs supplemented with AsA or ErA.

\begin{tabular}{ccc}
\hline Group & AsA & ErA \\
& \multicolumn{1}{c}{$(\mathrm{mg} / 100 \mathrm{~g}$ tissue $)$} & \\
\hline A & $0.20 \pm 0.09^{* \text {,ab }}$ & - \\
B & $2.29 \pm 0.42^{\text {acd }}$ & - \\
C & $4.01 \pm 0.54^{\text {bce }}$ & - \\
D & ND & ND \\
E & ND & ND \\
F & ND & $0.12 \pm 0.07^{\mathrm{c}}$ \\
G & $0.06 \pm 0.04^{\text {de }}$ & $0.45 \pm 0.12^{\mathrm{c}}$ \\
\hline
\end{tabular}

A, 1 mg AsA supplemented group; B, $5 \mathrm{mg}$ AsA supplemented group; C, $100 \mathrm{mg}$ AsA supplemented group; D, $1 \mathrm{mg}$ ErA supplemented group; E, $5 \mathrm{mg}$ ErA supplemented group; F, $20 \mathrm{mg}$ ErA supplemented group; G, $100 \mathrm{mg}$ ErA supplemented group. $*$ Mean \pm SE, $n=5-17$. Means in the same column with a common superscript letter are significantly different. ${ }^{\mathrm{a}, \mathrm{b}, \mathrm{d}, \mathrm{e}} p<0.001,{ }^{\mathrm{c}} p<0.05$. ND, not detected.

but a very small amount of AsA was found in group $G$ livers. On the other hand, ErA was found in the livers of groups $F$ and $G$ only. The ErA liver content of group $\mathrm{G}$ was higher than that of group $\mathrm{F}$, but was much lower than the AsA content of group $\mathrm{C}$ which was given the same amount of AsA as that of ErA given to group $\mathrm{G}$. 
Table 2 shows the AsA and ErA contents in the adrenal glands of guinea pigs administered AsA or ErA. In the AsA-supplemented guinea pigs, the AsA content increased with increasing dosage, and the same tendency for the ErA content was observed in animals administered only ErA. However, AsA was also found in the adrenal glands. When the amount of ErA administered was the same as that of AsA, the ErA content was much lower than that of AsA. Furthermore, the ErA content of group $\mathrm{G}$ adrenals was much lower than the AsA content in group B.

Table 2. AsA and ErA contents in adrenal glands of guinea pigs supplemented with AsA or ErA.

\begin{tabular}{ccc}
\hline Group & AsA & ErA \\
& \multicolumn{1}{c}{ (mg/100 g tissue $)$} & \\
\hline A & $8.3 \pm 1.7^{* \text {,abcdef }}$ & - \\
B & $23.6 \pm 4.1^{\text {bghij }}$ & - \\
C & $45.6 \pm 9.8^{\text {cklmn }}$ & - \\
D & $1.9 \pm 0.7^{\text {dgk }}$ & $0.9 \pm 0.4^{\text {p }}$ \\
E & $0.6 \pm 0.2^{\text {ahl }}$ & $1.9 \pm 0.5^{\mathrm{q}}$ \\
F & $1.2 \pm 0.4^{\text {eim }}$ & $4.0 \pm 1.1^{\circ}$ \\
G & $1.4 \pm 0.5^{\mathrm{fjn}}$ & $8.9 \pm 2.4^{\mathrm{pq}}$ \\
\hline
\end{tabular}

A, $1 \mathrm{mg}$ AsA supplemented group; B, $5 \mathrm{mg}$ AsA supplemented group; C, $100 \mathrm{mg}$ AsA supplemented group; D, $1 \mathrm{mg}$ ErA supplemented group; E, $5 \mathrm{mg}$ ErA supplemented group; F, $20 \mathrm{mg}$ ErA supplemented group; G, $100 \mathrm{mg}$ ErA supplemented group. ${ }^{*}$ Mean \pm SE, $n=5-17$. Means in the same column with a common superscript letter are significantly different. ${ }^{\mathrm{a}, \mathrm{g}, \mathrm{h}, \mathrm{i}, \mathrm{j}} p<0.001,{ }^{\mathrm{b}, \mathrm{c}, \mathrm{d}, \mathrm{e}, \mathrm{f}, \mathrm{k}, \mathrm{l}, \mathrm{m}, \mathrm{n}} p<0.01,{ }^{\mathrm{o}, \mathrm{p}, \mathrm{q}} p<0.05$.

Table 3. AsA and ErA contents in spleens of guinea pigs supplemented with AsA or ErA.

\begin{tabular}{ccc}
\hline Group & AsA & ErA \\
& \multicolumn{1}{c}{$(\mathrm{mg} / 100 \mathrm{~g}$ tissue $)$} & \\
\hline A & $2.4 \pm 0.6^{* \text { abc }}$ & - \\
B & $10.6 \pm 1.1^{\text {ade }}$ & - \\
C & $23.3 \pm 3.0^{\text {bef }}$ & - \\
D & ND & ND \\
E & ND & ND \\
F & trace & $0.3 \pm 0.1^{\mathrm{c}}$ \\
G & $0.3 \pm 0.2^{\text {cdf }}$ & $1.7 \pm 0.3^{\mathrm{c}}$ \\
\hline
\end{tabular}

A, $1 \mathrm{mg}$ AsA supplemented group; B, $5 \mathrm{mg}$ AsA supplemented group; C, $100 \mathrm{mg}$ AsA supplemented group; D, $1 \mathrm{mg}$ ErA supplemented group; E, $5 \mathrm{mg}$ ErA supplemented group; F, $20 \mathrm{mg}$ ErA supplemented group; G, $100 \mathrm{mg}$ ErA supplemented group. * Mean $\pm \mathrm{SE}, n=5-17$. Means in the same column with a common superscript letter are significantly different. ${ }^{\mathrm{a}, \mathrm{b}, \mathrm{d}, \mathrm{f}} p<0.001,{ }^{\mathrm{c}, \mathrm{e}} p<0.01$. ND, not detected. 
Table 4. AsA and ErA contents in kidneys of guinea pigs supplemented with AsA or ErA.

\begin{tabular}{ccc}
\hline Group & AsA & ErA \\
& \multicolumn{1}{c}{$(\mathrm{mg} / 100 \mathrm{~g}$ tissue $)$} & \\
\hline $\mathrm{A}$ & $0.24 \pm 0.12^{\text {*ab }}$ & - \\
$\mathrm{B}$ & $1.69 \pm 0.32^{\mathrm{bcdf}}$ & - \\
$\mathrm{C}$ & $3.49 \pm 0.57^{\mathrm{adeg}}$ & - \\
$\mathrm{D}$ & $\mathrm{ND}$ & $\mathrm{ND}$ \\
$\mathrm{E}$ & $\mathrm{ND}$ & $0.15 \pm 0.08$ \\
$\mathrm{~F}$ & $0.15 \pm 0.09^{\mathrm{ce}}$ & $0.19 \pm 0.14$ \\
$\mathrm{G}$ & $0.08 \pm 0.05^{\mathrm{fg}}$ & \\
\hline
\end{tabular}

A, $1 \mathrm{mg}$ AsA supplemented group; B, $5 \mathrm{mg}$ AsA supplemented group; C, $100 \mathrm{mg}$ AsA supplemented group; D, $1 \mathrm{mg}$ ErA supplemented group; E, $5 \mathrm{mg}$ ErA supplemented group; F, $20 \mathrm{mg}$ ErA supplemented group; G, $100 \mathrm{mg}$ ErA supplemented group. ${ }^{*}$ Mean \pm SE, $n=6-17$. Means in the same column with a common superscript letter are significantly different. ${ }^{\mathrm{a}, \mathbf{c}, \mathbf{e}, \mathbf{f}, \mathbf{g}} p<0.001,{ }^{\mathrm{b}} p<0.01,{ }^{\mathrm{d}} p<0.05$. ND, not detected.

Tables 3 and 4 show the contents of AsA and ErA in the spleen and kidneys, respectively. In these tissues, AsA was found in groups A, B, C, F, and G, and ErA was found in groups $F$ and $G$ only. The AsA and ErA retention patterns of the spleen and kidneys showed a similar tendency to those found in the liver.

\section{DISCUSSION}

Reiff and Free (7) reported that guinea pigs administered only $2 \mathrm{mg}$ ErA/day showed body weight loss, and AsA-deficient animals administered $100 \mathrm{mg}$ ErA/day also showed no recovery in body weight loss. On the other hand, Goldman et al. (8) observed a recovery in the body weight of animals administered $100 \mathrm{mg}$ ErA. In our study, we observed that even animals administered only $1 \mathrm{mg}$ ErA increased their body weights (Fig. 1). These differences may be partly due to differences in the diets used in these studies. Due to these contradictory results reported for antiscorbutic activity, it is necessary to clarify the vitamin $\mathrm{C}$ activity of ErA.

The weight gains of animals administered $5 \mathrm{mg}$ or more of ErA were similar to that of the animals administered $5 \mathrm{mg}$ AsA, which is considered to be adequate to keep guinea pigs healthy (Fig. 1). Thus, it may be concluded that ErA supplemented in a considerable amount may be able to replace AsA. Based on the body weight gain of guinea pigs administered AsA or ErA, it was found that ErA had more than one-twentieth the vitamin $\mathrm{C}$ activity of AsA.

In addition, the vitamin $C$ activity of ErA was roughly evaluated on the basis of the tissue contents of AsA and ErA in animals given AsA or ErA. AsA was found in the tissues of animals administered only $1 \mathrm{mg}$ AsA and the content increased as the amount of AsA administered increased. The AsA content in the tissues was 
highest in animals administered $100 \mathrm{mg}$ AsA, although the content did not seem to be proportional to the AsA dosage. On the other hand, ErA was not found in the liver, spleen, or kidneys, but was present in the adrenal glands of the animals administered $5 \mathrm{mg}$ or less of ErA. The ErA level in the tissues of the animals administered $20 \mathrm{mg}$ ErA was comparably lower than that of AsA in the animals administered $1 \mathrm{mg}$ AsA. The ErA content in animals administered $100 \mathrm{mg}$ ErA was similar to the AsA level in animals administered $1 \mathrm{mg}$ AsA. Moreover, in animals administered $100 \mathrm{mg}$ ErA, the total amount of AsA and ErA in the tissues did not differ much from that of AsA in animals administered $1 \mathrm{mg}$ AsA. These results were different from those reported by Fabianek and Herp (4) who found that the content of total AsA in the tissues of animals administered $10 \mathrm{mg}$ ErA was about $20 \%$ lower than that in animals administered $15 \mathrm{mg}$ AsA. However, their modified 2,4-dinitrophenylhydrazine method was unable to determine ErA and AsA separately. Furthermore, Pelletier and Godin (9) reported that the ErA content in the tissues of $40 \mathrm{mg}$ ErA-supplemented animals was lower than that of AsA in the $2 \mathrm{mg}$ AsA-supplemented animals. They measured the contents of AsA and ErA using a method based on the different rates of osazone formation of the oxidized diastereoisomers with 2,4-dinitrophenylhydrazine, which was not accurate enough to determine separately the contents of the two diastereoisomers.

Guinea pig tissues retained little ErA. However, a small amount of ErA was found in the tissues when a large amount of ErA was administered, although it did not completely replace AsA in the tissues. Therefore, the mechanism of the retention of ErA in the tissues may be different from that of AsA. However, in the adrenal glands, even though the amount administered was small, ErA was still found. This might be attributed to physiological characteristics of the adrenal glands which are quite different from other tissues.

When the amount of ErA administered was 20 times more than that of AsA, the ErA content in the tissues was much lower than that of AsA, although the body weight gains of the ErA-supplemented animals were almost the same as those of animals administered AsA. The difference in tissue content between the two isomers, AsA and ErA, may be due to a difference in their retention mechanisms in the tissues. Some studies $(10,11)$ suggested that AsA might be bound to a certain large biomolecule in the tissues, such as protein, but it is not known whether or not ErA exists in such a bound form. If there is not a special protein that binds with ErA, the amount of ErA retained in the tissues could be much lower than that of AsA, even if the amount of ErA uptake in the tissues were on the same level as that of AsA. It is necessary to clarify the retention mechanisms of both AsA and ErA in tissues.

Though it has been generally believed that ErA has one-twentieth the vitamin $\mathrm{C}$ activity of AsA, these results obtained in normal guinea pigs administered ErA indicate that ErA may have more than one-twentieth the vitamin $\mathrm{C}$ activity of AsA, and that sufficient amounts of ErA administered daily could prevent the occurrence of scurvy in guinea pigs. 


\section{REFERENCES}

1) Demole, V. (1934): On the physiological action of ascorbic acid and some related compounds. Biochem. J., 28, 770-773.

2) Yourga, F. J., Esselen, W. B., Jr., and Felers, C. R. (1944): Some antioxidant properties of D-isoascorbic acid and its sodium salt. Food Res., 9, 188-196.

3) Zilva, S. S. (1935): The behaviour of L-ascorbic acid and chemically related compounds in the animal body antiscorbutic activity in relation to retention by the organism. Biochem. J., 29, 1612-1616.

4) Fabianek, J., and Herp, A. (1967): Antiscorbutic activity of D-araboascorbic acid. Proc. Soc. Exp. Biol. Med., 125, 462-465.

5) Arakawa, N., Suzuki, E., Kurata, T., Otsuka, M., and Inagaki, C. (1986): Effect of erythorbic acid administration on ascorbic acid content in guinea pig tissues. $J$. Nutr. Sci. Vitaminol., 32, 171-181.

6) Suzuki, E., Kurata, T., Sanceda, N., and Arakawa, N. (1986): Effect of graded doses of erythorbic acid on ascorbic acid content of tissues of guinea pigs. J. Nutr. Sci. Vitaminol., 32, 335-342.

7) Reiff, J. S., and Free, A. H. (1959): Nutritional studies with isoascorbic acid in the guinea pig. Agric. Food Chem., 7, 55-56.

8) Goldman, H. M., Gould, B. S., and Munro, H. N. (1981): The antiscorbutic action of Lascorbic acid and D-isoascorbic acid (erythorbic acid) in the guinea pig. Am. J. Clin. Nutr., 34, 24-33.

9) Pelletier, O., and Godin, C. (1969): Vitamin C activity of D-isoascorbic acid for guinea pig. Can. J. Physiol. Pharm., 47, 985-991.

10) Fiddick, R., and Heath, H. (1967): The separation of bound ascorbic acid from rat adrenals by gel filtration. Biochim. Biophys. Acta, 136, 206-213.

11) Sumerwell, W. N., and Sealock, R. R. (1952): The determination of bound ascorbic acid in liver tissue. J. Biol. Chem., 196, 753-759. 